\title{
Heat production of the rat during the day as influenced by treadmill exercise
}

\author{
J. van Waversveld*, H. A. Boekholt, V. V. A. M. Schreurs and C. J. Zuurbier
}

Department of Animal Physiology, Wageningen Agricultural University, Haarweg 10, NL 6709 PJ Wageningen, Netherlands

Received 18 February 1987; accepted 11 August 1987

Key words: heat production, respiration, treadmill exercise, rat

\begin{abstract}
In this study the influence of interval and continuous treadmill exercise on heat production of rats was compared. We show that heat production is not only influenced during, but also after exercise. After a 7-week exercise period, heat production was increased during exercise, but decreased during the remainder of the day. The energy cost of interval exercise was more than half the energy cost of continuous exercise, which was 2 times the exercise intensity of interval exercise. During the remaining part of the day the heat production of the interval-exercised group was relatively less than that of the continuously exercised group. The respiratory quotient was lower during days with exercise than during days without exercise, but there was no difference between the interval-exercised group and the continuously exercised group.
\end{abstract}

\section{Introduction}

As part of a study on protein turnover (Schreurs et al., 1985), we have constructed 2 treadmills in order to investigate the adaptation of skeletal muscle to treadmill exercise with respect to protein metabolism. This paper deals with detailed results of the effects of treadmill exercise on heat production during a whole day. Shepherd $\&$ Gollnick (1976) used oxygen consumption as a measure for the intensity of exercise. As oxygen consumption and carbon dioxide production were measured, in the present experiments, heat production is preferred over oxygen consumption, since oxygen consumption depends on the substrates for oxidation.

\footnotetext{
* Present address: University of Leiden, Gorlaeus Laboratories, Department of Animal Physiology, P.O. Box 9502, 2300 RA Leiden, Netherlands.
} 


\section{Materials and methods}

\section{Animals}

Six, 3-month-old, male $F_{1}$ hybrids of female $\mathrm{R}$ and male $\mathrm{U}$ rats were divided at random into 3 groups. Two groups of rats were exercised 5 days per week, during the light period. The rats of the control group $(O)$ were not exercised. Before (Monday, 9:00 h) and after (Friday, 18:00 h) every 5 days exercise, all rats were weighed. The animals were housed individually, either in a cage or in a treadmill, at room temperature $\left(20^{\circ} \mathrm{C}\right)$, with a light period from 6:00 h till 20:00 h. Food and water were available ad libitum. Food intake and digestion could not be measured accurately while the animals were housed in the treadmills. However, a rough estimate could be obtained from the difference between food administration and food refusals.

\section{Treadmill exercise}

The 2 treadmills consisted of 2 work wheels each, $150 \mathrm{~cm}$ in circumference, in which the rats could be housed permanently. Group I (interval exercise) had 5 min rest after each 5 min exercise, whereas group $\mathrm{C}$ ran continuously. For both groups, the running speed and the duration of exercise were increased progressively during 4 weeks. Both groups had then reached an exercise level of 2 times $180 \mathrm{~min}$ per day at $15 \mathrm{~m} / \mathrm{min}$ with a pause of 2 hours between both periods. So, the running distance was $2700 \mathrm{~m} /$ day and $5400 \mathrm{~m} /$ day respectively. Exercise programs were controlled by automatic devices. After the adaptation period of 4 weeks, exercise was continued for another 3 weeks.

\section{Respiration measurements}

Two regular refrigerators of 1751 were modified to respiration chambers. Each chamber could contain one treadmill. Two types of measurements were carried out: (a) total daily $\mathrm{O}_{2}$ consumption and $\mathrm{CO}_{2}$ production during 48-hour periods, and (b) $\mathrm{O}_{2}$ consumption and $\mathrm{CO}_{2}$ production per $30 \mathrm{~min}$, calculated from continuous registration of $\mathrm{O}_{2}$ and $\mathrm{CO}_{2}$ content of the air leaving the chambers. All measurements were carried out in duplicate.

As usual, the respiration chambers were airconditioned, in order to maintain a constant ambient temperature $\left(20^{\circ} \mathrm{C}\right)$ and relative humidity $(60 \%)$. The air flow through the chambers was ca $3 \mathrm{l} / \mathrm{min}$. Ingoing and outgoing air of the chambers was sampled and analysed as described by van Es $(1958,1961)$. For the continuous registration the air was analysed by a Sybron Taylor Servomex $540 \mathrm{~A} \mathrm{O}_{2}$ analyser and a Telsec Process Analysers infrared TPA $311 \mathrm{CO}_{2}$ analyser. Data on temperature, humidity and barometric pressure were also recorded.

Heat production was computed from the data on gaseous exchange, using the formula of Brouwer (1965):

$$
H(\mathrm{~kJ})=16.18 \mathrm{O}_{2}+5.021 \mathrm{CO}_{2}-5.987 \mathrm{~N}-2.167 \mathrm{CH}_{4}
$$

where $\mathrm{O}_{2}, \mathrm{CO}_{2}$ and $\mathrm{CH}_{4}$ represent volumes consumed or produced (liters) and $\mathrm{N}$ 
the urinary nitrogen (grams). In previous experiments with rats we found that under normal feeding conditions the contribution of both the urinary nitrogen component and the methane component of the formula were negligible. Therefore, heat production was simply calculated as:

$$
H(\mathrm{~kJ})=16.18 \mathrm{O}_{2}+5.021 \mathrm{CO}_{2}
$$

All results were related to the metabolic weight:

$$
\mathrm{MW}=\sum_{i=1}^{n} W_{i}^{3 / 4}
$$

with body weight $W_{i}$ in $\mathrm{kg}$. The respiratory quotient was calculated as:

$$
\mathrm{RQ}=\mathrm{CO}_{2} / \mathrm{O}_{2}(\mathrm{v} / \mathrm{v})
$$

Heat production was measured before starting the adaptation period (Exp. 1) and 7 weeks later at maximum exercise level during days without exercise (Exp. 2) and with exercise (Exp. 3).

\section{Results and discussion}

\section{Body weight}

The influence of treadmill exercise on body weight is shown in Fig. 1. The difference in growth between the exercised groups and the control group seems primarily to be caused during the first week of housing in the treadmills. After the start of the exercise period, the growth rate of the exercised groups was approximately equal to the growth rate of the control group. There was no difference in growth between the exercised groups. Both exercised groups lost body weight during the 5 days exercise per week, but regained this during the weekend.

\section{Heat production}

The results of the daily respiration measurements are summarized in Table 1 . The heat production of group I and group $\mathrm{C}$ before the adaptation period (1I and $1 \mathrm{C}$ ) was approximately $35 \%$ higher than the heat production of the control group (1O). This is in accordance with the lower growth rate of these animals during this period (Fig. 1). At maximum exercise level there was a similar difference between the exercised groups ( $2 \mathrm{I}$ and $2 \mathrm{C}$ ) and the control group (2O). In addition, however, the heat production of the continuously exercised group was reduced. As a result of exercise the daily heat production of the interval-exercised group (3I) was raised with $28 \mathrm{~kJ} / \mathrm{day} / \mathrm{kg} \mathrm{MW} \mathrm{(5 \% ),} \mathrm{and} \mathrm{that} \mathrm{of} \mathrm{the} \mathrm{continuously} \mathrm{exercised} \mathrm{group} \mathrm{(3C)}$ with $55 \mathrm{~kJ} / \mathrm{day} / \mathrm{kg} \mathrm{MW}(10 \%)$. As compared with their levels at rest (Exp. 1 and 2$)$, the respiratory quotients of an exercise day (Exp. 3) were slightly less (ca. $5 \%$ ) for both exercised groups. This indicates a change in the use of substrate for oxidation: more fat instead of carbohydrate. This is in accordance with the loss of body weight during the 5 days exercise per week (Fig. 1). Because of the change in RQ during 


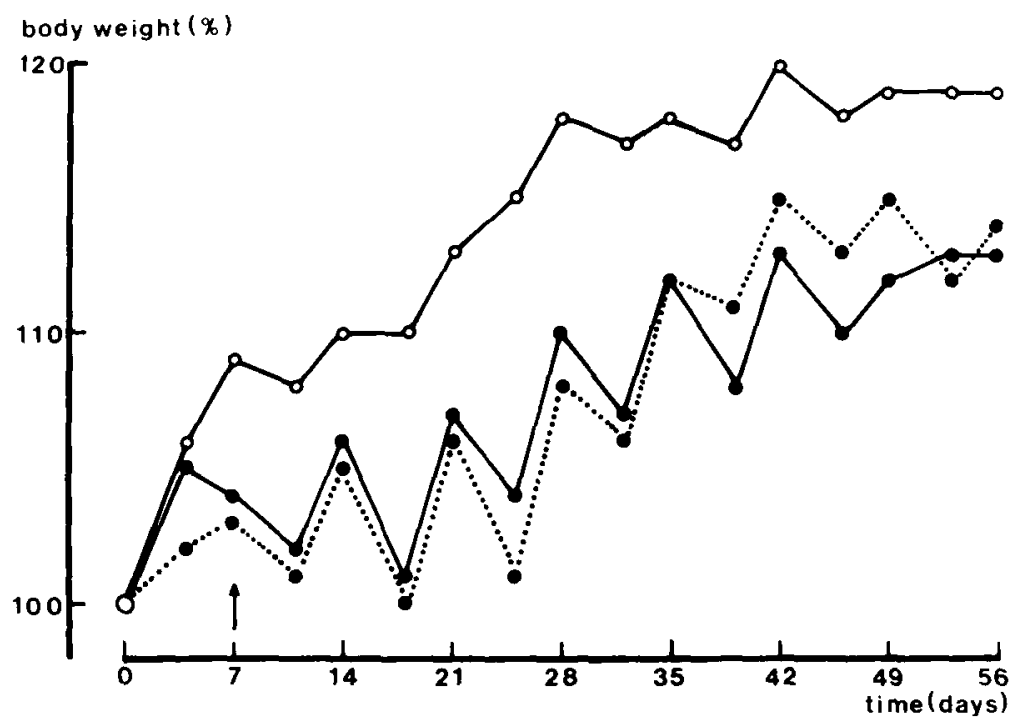

Fig. 1. Body weight (percentage of initial body weight) as influenced by exercise in a treadmill. $\mathrm{O}-\mathrm{O}$ : control group; $100 \%=355 \mathrm{~g},-10$ : continuously exercised group; $100 \%=328 \mathrm{~g}, \boldsymbol{0} \ldots$ :.. intervalexercised group; $100 \%=333 \mathrm{~g}$. The arrow indicates the start of the exercise period.

exercise, heat production has to be preferred as a measure for the intensity of exercise instead of oxygen consumption. A higher resting $\mathrm{O}_{2}$ consumption as a result of housing in the treadmills was reported by Shepherd \& Gollnick (1976). They suggested that rats may associate the housing in the treadmills with exercise. Prior to the adaptation period in our case, however, this cannot be the explanation. So, for the difference measured during that period, a change of environment had to be the cause of the delayed growth and the raised heat production. This despite the fact that the rats were placed in the treadmills several days before the first respiration measurement.

A similar effect of a change in environment was also seen during the maximum exercise period at rest (Exp. 2), when two additional measurements were carried out with the exercised rats in cages instead of in the treadmills. In the treadmills, daily heat production was 564 and $525 \mathrm{~kJ} / \mathrm{day} / \mathrm{kg} \mathrm{MW}$ (Table 1) for the intervalexercised group (2I) and the continuously exercised group (2C), respectively. In the cages this was 432 and $482 \mathrm{~kJ} / \mathrm{day} / \mathrm{kg} \mathrm{MW}$, respectively. On the other hand, it is very well possible that during this period the heat production measured in the treadmills is raised, compared to the heat production measured in the cages, because the rats associate housing in the treadmills with exercise, as suggested by Shepherd \& Gollnick (1976).

During the exercise period the exercised animals showed a small increase in food consumption. This small difference in food intake, however, can only have a minor influence on heat production. 
Table 1. Daily $\mathrm{O}_{2}$ consumption, $\mathrm{CO}_{2}$ production, heat production $(H)$ and respiratory quotient (RQ) as influenced by exercise in a treadmill.

\begin{tabular}{|c|c|c|c|c|c|}
\hline$\overline{\text { Exp. }^{1}}$ & Group $^{2}$ & $\begin{array}{l}\mathrm{O}_{2} \text { consumption } \\
(\mathrm{l} / \text { day } / \mathrm{kg} \mathrm{MW})\end{array}$ & $\begin{array}{l}\mathrm{CO}_{2} \text { production } \\
(1 / \text { day } / \mathrm{kg} \mathrm{MW})\end{array}$ & $\begin{array}{l}H \\
(\mathrm{~kJ} / \mathrm{day} / \mathrm{kg} \mathrm{MW})\end{array}$ & RQ \\
\hline 1 & $\mathrm{O}$ & 19.6 & 18.5 & 411 & 0.95 \\
\hline 1 & I & 26.8 & 24.7 & 558 & 0.92 \\
\hline 1 & $\mathrm{C}$ & 26.8 & 24.8 & 558 & 0.92 \\
\hline 2 & $\mathrm{O}$ & 20.9 & 19.2 & 434 & 0.92 \\
\hline 2 & I & 27.0 & 25.4 & 564 & 0.94 \\
\hline 2 & $\mathrm{C}$ & 25.1 & 23.6 & 525 & 0.94 \\
\hline 3 & I & 28.7 & 25.5 & 592 & 0.89 \\
\hline 3 & $\mathrm{C}$ & 28.0 & 25.1 & 580 & 0.90 \\
\hline
\end{tabular}

1 1: rest day before the start of the exercise period; 2 : rest day during maximum exercise level; 3 : exercise day during maximum exercise level.

${ }^{2}$ O: control group; I: interval-exercised group; C: continuously exercised group.

Table 2. Heat production during light and dark periods calculated from the heat production per $30-\mathrm{min}$ periods (Fig. 2).

\begin{tabular}{|c|c|c|c|}
\hline \multirow[t]{2}{*}{ Exp. $^{1}$} & \multirow[t]{2}{*}{ Group $^{2}$} & \multicolumn{2}{|c|}{ Heat production $(\mathrm{kJ} / \mathrm{min} / \mathrm{kg} \mathrm{MW})$} \\
\hline & & light & dark \\
\hline 1 & $\mathrm{O}$ & 0.28 & 0.33 \\
\hline 1 & I & 0.34 & 0.42 \\
\hline 1 & $\mathrm{C}$ & 0.38 & 0.45 \\
\hline 2 & $\mathrm{O}$ & 0.27 & 0.34 \\
\hline 2 & I & 0.36 & 0.43 \\
\hline 2 & $\mathrm{C}$ & 0.35 & 0.39 \\
\hline 3 & 1 & $0.58^{*}$ & 0.39 \\
\hline 3 & C & $0.63^{*}$ & 0.37 \\
\hline
\end{tabular}

${ }^{1} 1$ : rest day before the start of the exercise period; 2 : rest day during maximum exercise level; 3 : exercise day during maximum exercise level.

${ }^{2}$ O: control group; I: interval-exercised group; C: continuously exercised group.

* Value of exercise period instead of light period.

In Fig. 2 and Table 2 the results of the continuous registrations are shown. On days without exercise (Exp. 1 and 2), the heat production during the dark periods was $12-26 \%$ higher than during the light periods. This is due to the fact that as a rule rats are more active during the dark periods, e.g. they eat and drink at night. During exercise, the heat production was $0.22 \mathrm{~kJ} / \mathrm{min} / \mathrm{kg} \mathrm{MW}(60 \%)$ higher for the interval-exercised group (3I vs $2 \mathrm{I}$ ) and $0.28 \mathrm{~kJ} / \mathrm{min} / \mathrm{kg} \mathrm{MW} \mathrm{(80 \% )} \mathrm{for} \mathrm{the} \mathrm{continu-}$ ously exercised group ( $3 \mathrm{C}$ vs $2 \mathrm{C}$ ). During the dark periods of the exercise days, the 

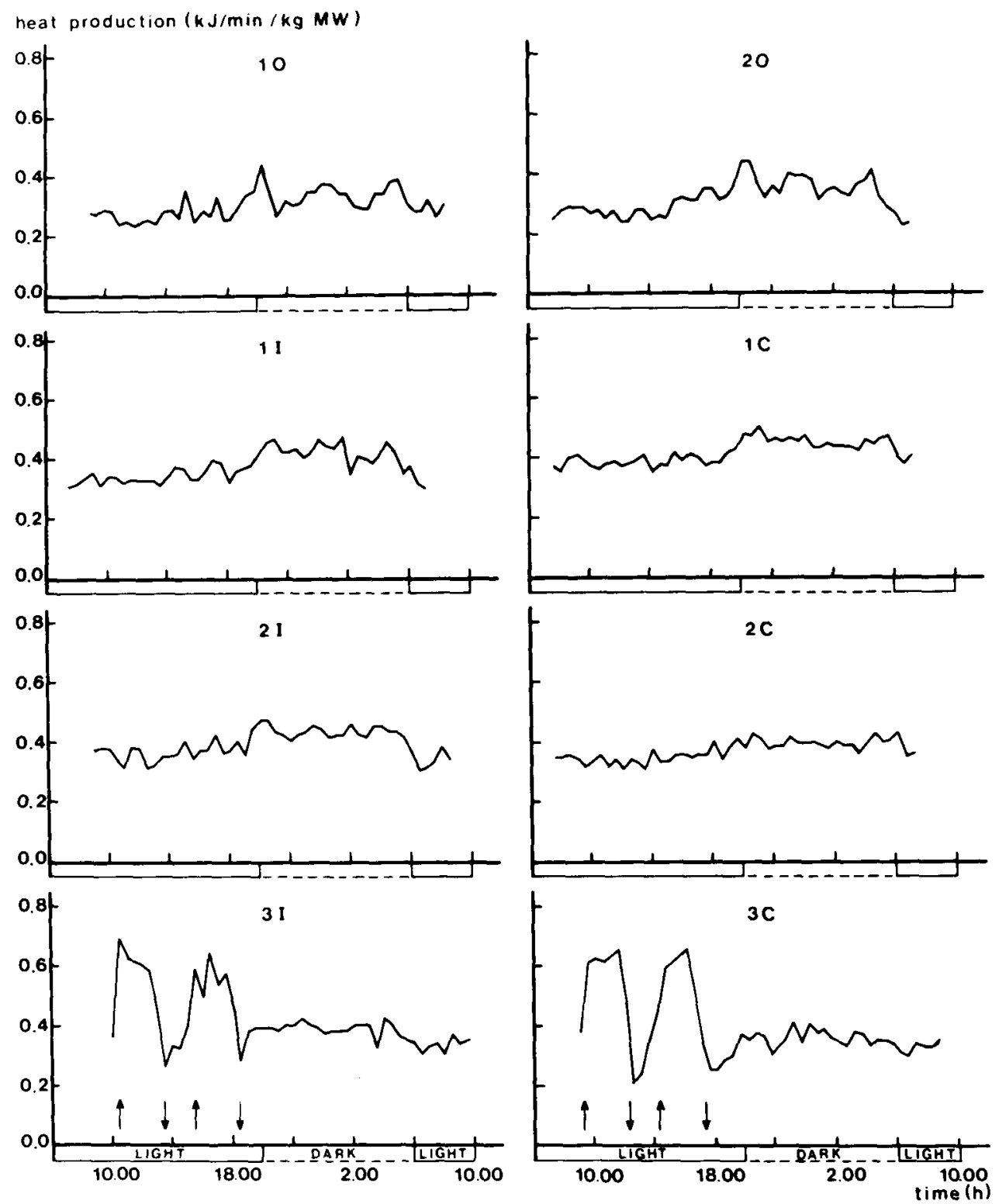

Fig. 2. Heat production per $30 \mathrm{~min}$ during the day as influenced by exercise in a treadmill. 1: rest day before the start of the exercise period; 2: rest day during maximum exercise level; 3 : exercise day during maximum exercise level. $\mathrm{O}$ : control group; I: interval-exercised group; $\mathrm{C}$ : continuously exercised group. $\uparrow:$ start of exercise, $\downarrow$ : end of exercise. 
heat production of both exercised groups (3I and 3C) was less than during the dark periods of the rest days (2I and 2C): 9 and $5 \%$, respectively.

From Table 2 the energy cost of exercise can be calculated: $79 \mathrm{~kJ} / \mathrm{kg} \mathrm{MW}$ for the interval-exercised group (3I) and $101 \mathrm{~kJ} / \mathrm{kg} \mathrm{MW}$ for the continuously exercised group (3C). The decrease of heat production during the dark periods of an exercise day as result of exercise can also be calculated from Table $2: 24 \mathrm{~kJ} / \mathrm{kg} \mathrm{MW}$ and 12 $\mathrm{kJ} / \mathrm{kg} \mathrm{MW}$, respectively. These results, combined with the raise of the daily heat production of an exercise day (Table 1), give the decrease of heat production during the remaining light period of an exercise day: $27 \mathrm{~kJ} / \mathrm{kg} \mathrm{MW}$ and $34 \mathrm{~kJ} / \mathrm{kg} \mathrm{MW}$, respectively. This implies that the exercised animals on an exercise day, compared to a rest day, were less active during the dark period and the remaining light period. Furthermore it can be seen that the interval-exercised group was relatively less active during the total of non-exercise periods (dark period and remaining light period together) than the continuously exercised group.

The heat production of the control group during the light period is in good agreement with the heat production calculated from the resting $\mathrm{O}_{2}$ consumption reported by Rothwell et al. (1982).

The raise of the daily heat production of the interval-exercised group during days with exercise (3I vs 2I, Table 1) was ca $50 \%$ of the raise of the continuously exercised group ( $3 \mathrm{C}$ vs $2 \mathrm{C}$ ). This is in accordance with the differing activity of the exercised groups, 2700 and $5400 \mathrm{~m} /$ day, respectively. However, regarding only the heat production during the exercise period (Table 2), the raise of 3 I was ca $75 \%$ of that of $3 \mathrm{C}$. Observation of the rats made it clear that the interval-exercised animals were also fairly active during the 5-min rest intervals. So the activity differed less than a factor 2 . The relatively lower heat production during the total non-exercise period (dark period and remaining light period together) compensated for this extra activity. When considering the influence of exercise on metabolism it is therefore important to compare not only heat production during the exercise periods, but also during rest, since exercise also seems to change metabolism during the non-exercise period of the day.

\section{Acknowledgements}

The authors are indebted to Mr A. G. M. Roos, Mr G. H. J. Leenders and Mr W. R. Bijlsma for constructing the treadmills. They also wish to thank Mr J. E. Vogt and Mr M. J. N. Los for their contribution to the respiration measurements.

\section{References}

Brouwer, E., 1965. Report of the Subcomittee on constants and factors. Proceedings 3rd Symposium on Energy Metabolism, Troon, Scotland. EAAP Publication 11: 441-443.

Es, A. J. H. van, 1958. Gas analysis in open circuit respiration chambers. Proceedings 1st Symposium on Energy Metabolism, Copenhagen, Danmark. EAAP Publication 8: 132-137.

Es, A. J. H. van, 1961. Between-animal variation in the amount of metabolisable energy required for the maintenance of cows. Verslagen Landbouwkundige Onderzoekingen 67: 5. 
Rothwell, N. J., M. E. Saville \& M. J. Stock, 1982. Effects of feeding a 'Cafetaria' diet on energy balance and diet-induced thermogenesis in four strains of rat. Journal of Nutrition 112: 1515-1524.

Schreurs, V. V. A. M., H. A. Boekholt, R. E. Koopmanschap \& W. van Rotterdam, 1985. Relative synthesis rate of individual muscle proteins: a new approach. Netherlands Journal of Agricultural Science 33: 297-302.

Shepherd, R. E. \& P. D. Golnick, 1976. Oxygen uptake of rats at different work intensities, Pflügers Archiv für die gesammte Physiologie des Menschen und der Tiere 362: 219-222. 